\title{
Effect of Feeding on Reproductive Performance in Finnish Dairy Cows
}

\author{
By P. V. A. Miettinen
}

Department of Anatomy, University of Kuopio, Finland.

\begin{abstract}
Miettinen, P. V. A.: Effect of feeding on reproductive performance in Finnish dairy cows. Acta vet. scand. 1990, 31, 453-458. - The effect of 2 types of feeding on the involution of the genital tract and on the fertility was studied in 79 Finnish dairy cows on a research farm. The cows were fed twice a day with home-produced feed in accordance with the Finnish feeding standard. The cows were divided according to the type of feed into a hay-urea group and a silage group. The cows were examined clinically by rectal palpation 3 times a week during 8 weeks postpartum. The time required for the complete involution of uterus and cervix was recorded. The cows in the silage group had a significantly longer time in uterine involution, a lower fertility rate at first insemination and a longer interval from calving to conception than those in the hay-urea group. The pregnancy rate in the first insemination was in the hay-urea group $91 \%$ and in the silage group $57 \%$. The interval between calving and the first insemination was shorter in the hay-urea group than in the silage group; $71.4 \pm 10.6$ and $74.0 \pm 10.3$ days, respectively. The interval between calving and conception was in the hay-urea group significantly $(\mathrm{p}<0.01)$ shorter than in the silage group; $74.8 \pm 15.1$ and $89.5 \pm 24.4$ days, respectively.
\end{abstract}

fertility; involution; puerperium; pregnancy; rectal palpation.

\section{Introduction}

In dairy cows a calving interval of 1 year is generally considered optimal. This requires that the animals are pregnant by 85 days postpartum. Adequate nutrition is essential before and after calving if acceptable estrus and rebreeding are to be obtained.

Excess feeding before calving has a negative influence on involution of the uterus (Lotthammer 1974, Farries 1979) and on the activity of the ovaries (Lotthammer 1974). A delayed uterine involution often interferes with the rebreeding of the cow. Retardation in uterine involution is found together with a quiescent state of the ovaries during the first 3-4 weeks postpartum (Bostedt et al. 1976) or with ovarian cysts and delayed ovulation (Lotthammer 1974). The first follicles can be palpated 7-10 days postpartum
(Morrow et al. 1969). Parturition accompanied by milk fever, retained fetal membranes, metritis and/or ketosis cause a delay in the onset of the first estrus (Morrow et al. 1969). Excessive intake of protein has a negative influence on fertility (Lotthammer \& Farries 1977). The breed (Larsson et al. 1984) and energy balance during the first days of lactation are also important for the onset of ovarian activity (Butler et al. 1981). The interval from parturition to conception is longer in cows on a high prepartum energy concentration (Flipot et al. 1988). The lower the feeding after calving the higher is the negative influence of excess feeding before calving (Lotthammer 1979).

The energy level influences the pregnancy rates. A low pregnancy rate occurs in cows fed at a low energy level after calving, be- 
cause the cows fail to show estrus (Dunn et al. 1969).

The uterine involution is completed by 25 days (Morrow et al. 1966, Miettinen, 1990). The cattle breed (Marion et al. 1968, Fonseca et al. 1983, Larsson et al. 1984) and parity (Rasbech 1950, Marion et al. 1968, Fonseca et al. 1983, Larsson et al. 1984) may influence the involution process as well. However, no differences have been found in the uterine or cervical involution of 3 Finnish cattle breeds (Miettinen 1990).

The importance of the herd manager in the detection of oestrus is well known. Indeed, Whitmore (1984) has suggested that the primary reason for long calving intervals is a failure to observe estrus and thus breeding is delayed.

Francos et al. (1977) and Bogin et al. (1982) have reported a relationship between feeding and fertility. Although clinicians generally agree that nutrition influences the reproductive efficiency in cattle, there is little information about the effect of different types of feeding on the reproduction under the same management.

The purpose of the present study was to evaluate the influence of hay-urea and silage feeding on the involution of genital tract and on the fertility of the Finnish dairy cows.

\section{Materials and methods}

Animals

In this study a total of 79 cows were included; 15 of them were primiparous cattle and the rest were calving for the third time. Animals consisted of Finncattle (FC, $n=11)$ and the Finnish Ayrshire (AY, n = 34) and Friesian breeds ( $F R, n=34)$. The calving season was from April to August. The cows with gestation period less than 260 days were regarded as abnormal and were therefore excluded from the study. Difficulties in calving and veterinary treatment were registered. All animals included were pregnant before 160 days postpartum and had a normal and easy calving (unassisted or assisted by 1 person).

\section{Management}

The experimental cows were housed indoors and they were fed individually with homeproduced feed on a research farm. Daily feed intake and feed refusals were recorded. The cows were divided according to the type of feed into a hay-urea group ( $n=44: 20 \mathrm{AY}$, 18 FR, 6 FC; 8 primipara) and a silage group ( $\mathrm{n}=35$ : $14 \mathrm{AY}, 16 \mathrm{FR}, 5 \mathrm{FC}$; 7 primipara). Both groups were fed a concentrate containing $2 / 3$ barley and $1 / 3$ oats according to the daily milk yield in accordance with the Finnish feeding standards. The rations were designed to contain the same amounts of nutrients in terms of energy and digestible crude protein. All animals in the hay-urea group were allowed a free access to dry hay and $2 \%$ urea was added to the concentrate as a source of nitrogen. The silage group was allowed a free access to grass silage and the amount of hay was limited to $1 \mathrm{~kg}$ per day. The cows were allowed to eat twice a day: in the morning from 6 to 10 am and in the afternoon from 2 to $6 \mathrm{pm}$. The average milk yield of the herd was about $5500 \mathrm{~kg}$. External signs of heat were checked 3 times daily by the herdsmen.

\section{Methods}

The cows were examined clinically 3 times a week between calving and the first insemination, which normally took place at the first heat by 8 weeks after the previous delivery. The examination included an inspection of the vulva and perineum as well as a rectal palpation of the cervix, uterine horns and ovaries. The diameters of cervix and both uterine horns at the external bifurcation were estimated by palpation and reported in centimeter. One examiner carried out all 
studies, but previous findings were not available during the subsequent examination.

The uterine involution was considered complete, when both horns were nearly symmetrical and there was no further change between 2 consecutive examinations. For each animal the time was recorded when the uterus was within or at the edge of the pelvic cavity, i.e., in the pelvic cavity position (P.C.P.). The end of the cervical involution was the time required for the midcervix diameter to reach the nadir. The interval from parturition to the appearance of the first palpable follicle was recorded. The pregnancy rate at the first insemination and the interval from calving to conception were obtained for each cow. The pregnancies were confirmed by rectal palpation 6-7 weeks after insemination and in any doubtful case the examination was repeated 1-2 weeks later. The pregnancy of all cows were followed for a period of more than 4 months.

The means $( \pm$ S.D.) of the measurements were calculated. Student's t-test was used in the statistical comparison of the results.

\section{Results}

The time required for the uterus to reach the P.C.P. position was $15.4 \pm 2.1$ days and $16.6 \pm 2.3$ days for the hay-urea and silage groups $(\mathrm{p}<0.05)$, while a complete uterine involution for these groups was obtained at $24.6 \pm 3.4$ and $26.4 \pm 3.5$ days $(p<0.05)$, respectively (Table 1).
Table 1. The attainment of pelvic cavity position (P.C.P.) and the time of involution of uterus and cervix in hay-urea and silage groups are given in days. The diameter of the parous horn in $\mathrm{cm}$ was obtained at 3 weeks postpartum.

\begin{tabular}{lccc}
\hline Parameter & Hay-urea & Silage & Significance \\
\hline $\begin{array}{l}\text { P.C.P. } \\
\begin{array}{l}\text { Involution of } \\
\text { uterus }\end{array}\end{array}$ & $15.4 \pm 2.1$ & $16.6 \pm 2.3$ & $\mathrm{p}<0.05$ \\
$\begin{array}{l}\text { Involution of } \\
\text { cervix }\end{array}$ & $30.1 \pm 3.6$ & $26.4 \pm 3.5$ & $\mathrm{p}<0.05$ \\
$\begin{array}{l}\text { Diameter of } \\
\text { parous horn }\end{array}$ & $3.6 \pm 0.7$ & $4.0 \pm 0.6 \pm 2.9$ & $\mathrm{~N} . \mathrm{S}$ \\
\hline
\end{tabular}

At 3 weeks postpartum the diameter of the parous uterine horn was $3.6 \pm 0.7 \mathrm{~cm}$ and the corresponding value for the cows in silage group $4.0 \pm 0.5 \mathrm{~cm}(\mathrm{p}<0.05)$. The involution of the cervix was quite similar and was complete at $30.1 \pm 3.7$ days for the hay-urea and at $29.6 \pm 2.9$ days for the silage group. The first palpable follicle was found at $15.0 \pm 3.9$ and $17.8 \pm 5.7$ days $(p$ $<0.05)$ in the hay and in the silage groups, respectively. The pregnancy rate in the first insemination was higher in the hay-urea group $(91 \%)$ than in the silage group (57\%). The interval between calving and the first insemination was shorter in the hay-urea group than in the silage group (Table 2), but the difference was not significant between the groups. However, the interval between calving and conception was in the hay-urea group significantly $(p<0.01)$ shorter than in the silage group when all cows or cows in

Table 2. Intervals between calving and first insemination (1st AI) and calving and conception in days in the first and third parity.

\begin{tabular}{|c|c|c|c|c|c|c|}
\hline \multirow[t]{2}{*}{ Group } & \multicolumn{2}{|c|}{ 1. Parity } & \multicolumn{2}{|c|}{ 3. Parity } & \multicolumn{2}{|c|}{ 1.+3. Parity } \\
\hline & 1st AI & conception & Ist AI & conception & 1st AI & conception \\
\hline Hay-urea & $73.2 \pm 15.3$ & $76.0 \pm 22.0$ & $71.1 \pm 9.4$ & $75.0 \pm 14.6$ & $71.4 \pm 10.6$ & $74.8 \pm 15.1$ \\
\hline Silage & $\begin{array}{c}74.0 \pm 12.5 \\
\text { N.S }\end{array}$ & $\begin{array}{c}97.7 \pm 25.7 \\
\text { N.S }\end{array}$ & $\begin{array}{c}74.0 \pm 9.7 \\
\text { N.S }\end{array}$ & $\begin{array}{c}87.5 \pm 24.0 \\
p<0.01\end{array}$ & $\begin{array}{c}74.0 \pm 10.3 \\
\text { N.S }\end{array}$ & $\begin{array}{c}89.5 \pm 24.4 \\
p<0.01\end{array}$ \\
\hline
\end{tabular}


the third lactation were compared. In the first lactation the difference is not significant due to a small number of cows in this group; however, the trend was similar to that in the third lactation.

\section{Discussion}

It is well known that nutrition influences the reproductive efficiency in cattle. The purpose of the present study was to evaluate the influence of hay-urea and silage feeding on the involution of the genital tract and on the reproductive performance in Finnish dairy cows kept in a strict management environment. The diameters of cervix and uterine horns were estimated by rectal examination rather than measured. However, all comparisons were made with animals treated identically and the data were collected by the same examiner. In contrast to the previous report of Heinonen et al. (1988), the present study showed a significant difference in reproductive efficiency between the feeding groups. This may be partly due to different criteria of including the animals. In this study only cows with identical conditions in calving performance were included in each group. All cows included were also found pregnant within 3 months after insemination during the follow-up period.

The main observations in this study were that the silage group displayed a significantly longer time of uterine involution, had a lower fertility rate at the first insemination, and the interval from calving to conception was longer than in the hay-urea group. The high fertility in hay-group could be due to the strictly limited feeding of concentrates (maximal $12.5 \mathrm{~kg}$ per day) according to the milk yield and in relation to the amount of hay. Previously, Francos et al. (1977) and Bogin et al. (1982) also found that the feed composition has an effect on conception rate of the milking cows. Higher levels of con- centrates were negatively related to the conception rate. In the silage group the low fertility could be due to an imbalance in the quality and quantity of roughage.

In contrast to the results of Heinonen et al. (1988) the type of feed affected the uterine involution in cows of the third lactation and this effect was similar to that reported for the involution in the first lactation. This may be due to an excessive feeding (Lotthammer 1974, Farries 1979) or an excess of protein before calving (Lotthammer \& Farries 1977). The feeding of grass silage causes easily too high an intake of protein especially when the amount of other types of roughage is limited. The delayed onset of ovarian activity in the silage group corroborates the observations of Lotthammer (1974, 1979) and Bostedt (1976), who showed that a delayed uterine involution influences the ovarian function.

The low pregnancy rate at the first insemination in the silage group is in agreement with results reported for the second parturition (Heinonen et al. 1988). This may be due to a lower energy level in late puerperium in the silage group than in the hay-urea group (Miettinen, unpublished), although the energy content and the amount of digestible crude protein in rations were calculated to meet the daily needs in both groups. This supports the finding of Dunn et al. (1969), who suggested that a low pregnancy rate occurred in the cows fed at low energy level after calving, because the animals failed to show estrus. The importance of the herd manager in the detection of estrus is well known. Whitmore (1984) suggested that the primary reason for long calving intervals is the failure to observe the estrus and thus breeding is delayed, but it is also well known that many high-yielding cows are unable to consume sufficient food for their production and maintenance requirements. In this study 
the type of feeding seemed to have an influence on fertility strictly under the same management.

In conclusion, the results of this study indicate that the type of feed can have a significant effect on the reproductive efficiency in the dairy cows. The uterine involution in cows of the silage group took significantly longer time, the fertility rate at first insemination was lower, and the interval from calving to conception was longer than in those of the hay-urea group. Therefore, if shorter calving intervals are desired, adequate nutrition is essential before and after calving.

\section{Acknowledgement}

The author wishes to thank Prof. T. Vanha-Perttula for critical reviewing of the manuscript.

\section{References}

Bogin E. Avidar $Y$, Davidson M, Gordin S, Israeli $B$ - $A$ : Effect of nutrition on fertility and blood composition in the milk cow. J. Dairy Res. 1982, 49, 13-23.

Bostedt $H$, Reissinger $H$, Günzler D: Klinische Erhebungen über den Verlauf der Puerperalperiode bei Rindern aus Beständen mit Fertilitätproblemen. (Clinical findings on the course of the puerperal period in cows on farms with fertility problems). Berl. Münch. Tierärtzl. Wschr. 1976, 89, 24-28.

Butler WR, Everett $R W$, Coppock CE: The relationships between energy balance, milk production and ovulation in postpartum Holstein cows. J. Anim. Sci. 1981, 53, 742-748.

Dunn TG, Ingalls JE, Zimmermann DR, Wiltbank JN: Reproductive performance of 2-year-old Hereford and Angus heifers as influenced by pre- and post-calving energy intake. J. Anim. Sci. 1969, 29, 719-726.

Farries E: Fütterung von Hochleistungskühen vor dem Kalben - Neue Erkenntnisse zum Einfluß auf Milchleistung. Gesundheit und Fruchtbarkeit. (Feeding high-yielding cows before calving. New results on its influence on milk production, health and fertility). Tierzüchter 1979, 3, 326-328.

Flipot PM, Roy Gl, Dufour JJ: Effect of peripartum energy concentration on production performance of Holstein cows. J. Dairy Sci. 1988, 71, 1840-1850.

Fonseca FA, Britt JH, McDaniel BT, Wilk JC, Rakes $A H$ : Reproductive traits of Holsteins and Jerseys. Effects of age, milk yield, and clinical abnormalities on involution of cervix and uterus, ovulation, estrous cycles, detection of estrus, conception rate, and days open. J. Dairy Sci. 1983, 66, 1128-1147.

Francos $G$, Davidson $M$, Mayer $E$ : The influence of some nutritional factors on the incidence of repeat breeder syndrome in high producing dairy herds. Theriogenology 1977, 7, 105-111.

Heinonen K, Miettinen P, Savolainen E, Tuovinen $V$, Alanko $M$ : Postpartum reproductive function in Finnish Ayrshire and Friesian cows after three subsequent parturitions. Acta vet. scand. 1988, 29, 231-238.

Larsson $K$, Jansson L, Berglund B, Edqvist L-E, Kindahl $H$ : Postpartum reproductive performance in dairy cows. Acta vet. scand. 1984, 25, 445-461.

Lotthammer $K-H$ : Häufige Fütterungsfehler als Ursache der Herdensterilität. (Common nutritional deficiencies causing herd sterility). Prakt. Tierarzt, Sonderheft collegium veterinarium, 1974, 55, 38-43.

Lotthammer $K-H$ : Einflu $B$ der Fütterung und Futterproduktion auf Gesundheit und Fruchtbarkeit von Milchrindern. (Influence of feeding and feed production on the health and fertility of dairy cattle). Tierärztl. Prax. 1979, 7, 425-438.

Lotthammer $K-H$, Farries $E$ : Influence of different intake of digestible protein and energy antepartum and postpartum on some metabolites in blood plasma of dairy cows. Israel $\mathrm{J}$. Med. Sci. 1977, 13, 435.

Marion GB, Norwood JS, Gier HT: Uterus of the cow after parturition: Factors affecting regression. Amer. J. vet. Res. 1968, 29, 71-75.

Miettinen PVA: Uterine involution in Finnish dairy cows. Acta vet. scand. 1990, 31, 181185. 
Morrow DA, Roberts SJ, McEntee K, Gray, HG: Postpartum ovarian activity and uterine involution in dairy cattle. J. Amer. vet. med. Assoc. 1966, 149, 1596-1609.

Morrow DA, Roberts SJ, McEntee K: Postpartum ovarian activity and involution of the uterus and cervix in dairy cattle. 1. Ovarian activity. Cornell Vet. 1969, 59, 173-189.

Rasbech NO: Den normale involutio uteri hos koen. (The normal involution of the uterus in the cow). Nord. Vet.-Med. 1950, 2, 655-687.

Whitmore HL: Pathophysiology of the puerperium: Management factors. Proc. 10th Int. Congr. Anim. Reprod. and A.I., Illinois 1984, IV, III-34-40.

\begin{abstract}
Sammanfattning
Inflytande av foder på reproduktiva funktioner hos finska miölkkor.

Ändamålet med den föreliggande undersökningen var att studera inverkan av foder på reproduktiva funktioner hos finska mjölkkor. Korna indelades på basis av utfodring i två grupper. en hö-ureagrupp och ensilagegrupp. 79 kor undersöktes genom rektalpalpation 3 gånger per vecka under 8 veckors tid postpartum på en försöksgård. Tiden från kalving till fullständig involution av livmoder och cervix registrerades. Tiden mellan kalving och dräktighet mättes och andelen lyckade dräktigheter vid första insemination uträknades. Typen av foder hade en signifikant betydelse för livmoderns involution, andelen lyckade dräktigheter vid första insemination och tiden mellan kalving och dräktighet.
\end{abstract}

(Received October 7, 1989; accepted January 19, 1990).

Reprints may be requested from: P. V. A. Miettinen, Department of Anatomy, University of Kuopio, P. O. Box 6, SF-70211 Kuopio, Finland. 